\title{
On the Theme of Thomas Hardy's Jude the Obscure
}

\author{
Guorong $\mathrm{Lu}^{1} \&$ Zhehui Zhang ${ }^{1}$ \\ ${ }^{1}$ School of Foreign Languages, Inner Mongolia University for Nationalities, Inner Mongolia Autonomous \\ Region, China \\ Correspondence: Guorong Lu, School of Foreign Languages, Inner Mongolia University for Nationalities, 536 \\ Huolinhe Street West, Tongliao, Inner Mongolia Autonomous Region, China. E-mail: 18747555374@qq.com
}

Received: June 20, 2019 Accepted: July 11, 2019 Online Published: August 20, 2019

doi:10.5539/ells.v9n3p15 URL: https://doi.org/10.5539/ells.v9n3p15

\begin{abstract}
Thomas Hardy's Jude the Obscure got the most attention of the critical world in the nineteenth century of Britain. The theme was always regarded as the embodiment of original sin, pessimism and voluntarism. However, when the theme is analyzed again, it will be found something totally different. Hence, three-phase patterns are to be singled out for a case study in order to shed light upon some facts and conclusions. The first stage is the expression of optimism from the perspective of symbolism; the second stage is the representation of conflict between character and environment in light of Darwinism; the third stage is the exploration of rationality from the viewpoints of religion and feminism. What can be learned is that the story is meant to show readers the kindness tendency, the courage to face the harsh reality and a sense of rationality.
\end{abstract}

Keywords: writing theme, kindness tendency, optimism, rationality

\section{Introduction}

Thomas Hardy (1840-1928) is a literary giant in the late Victorian age. Virginia Woolf remarked that "the death of Thomas Hardy leaves English fiction without a leader" (Taylor, 1981, p. 32). Among all his Literature works, Jude the Obscure is the most controversial one. It complains the unreasonable education system, the subhuman institution of marriage, the hypocrisy of religion as well as the entire capitalist system in the late Victorian Time and naturally got the most attention of the critical world in the nineteenth century of Britain.

Hitherto the last century, over 80 tremendous amounts of works with respect to Hardy have been published or produced by scholars. What's more, Dorchester hold the conference concerning him twice a year, in which many scholars exchange ideas on him and the related literary works. However, since the year 2000, other than the canonical works of Hardy, the new fields haven't been explored.

At that time, the book received a storm of attack than objective appraisals. On the opposite wing, there are strong voices speaking for and against. Objective views or comments have been arisen from home and abroad out of current theories and the deep study on Jude.

When it comes to the comments from abroad, there are many critics mainly focusing on the analyses in some respects of psychology, feminism, formalism, Marxism, ecological criticism, archetypal criticism, symbol theory, ethical point, the theory of space and so on. Research on Hardy in the West has been flourishing since 1980, with breakthroughs in both quantity and quality. The British writer, E. M. Foster says Hardy wants to show us a sense of determinism and a book a tragedy (Foster, 2009, p. 82).

This thesis is also designed to focus on the research of the creation of the theme. However, this paper discusses the methods of how the writer deals with the comparison and contrast of details; how he sets the attitudes, choices and futures of different characters. After analyzing the key steps, a three-phase pattern, in the theme creation, it is found to differ from the previous views completely. There is more to it than just the embodiment of original sin, pessimism and voluntarism. The enlightenment can be learned is that the novel conveys readers the kindness tendency, the courage to face the harsh reality and a sense of rationality.

\section{Hardy's Expression of Optimism from the Perspective of Symbolism}

Thomas Hardy was eight years old when he went to village school and by age sixteen, he apprenticed himself to an architect. In his pursuit of his long-cherished wish of being a priest, he went to London to study architect, literature, theology and philosophy. He taught himself to read Greek theological works. Thus, Jude the Obscure 
was somewhat Hardy's representative novels. He uses numerous symbols and images to show his intended viewpoints which are totally different from the secular ones.

\subsection{The Images of Clacker and Birds}

"In its broad sense symbolism is the use of one subject to suggest another, or in literature, the practice of representing objects or ideas by symbols or giving things a symbolic (associated) character and meaning"(Frye \& Northrop, 1957). The abundant use of symbolism widely employed in Jude the Obscure is Hardy's common stylistic trait. Many object images existing during his childhood time appear time and again. The clacker, appearing in the beginning of the novel Jude the Obscure, is the instrument Jude used or rattled briskly. "You shall have some dinner-you shall...Eat, then, my dear little birdies, and make a good meal!" "His clacker he had by this time thrown away from him, as being a mean and sordid instrument, offensive both to the birds and to himself as their friend" (Hardy 2010, p. 9). In this short extract, two objects as the symbols will be discussed. For one thing, the birds represent Sue, like Jude, who is also ostracized by the society out of the personality peculiar to her. Jude was beaten up by the employer Troutham for his allowing the birds to "destroy" the field. So, the charter of compassion starts right here. He loves Sue so deeply that he is determined to be with her regardless of the secular, narrow foolish values. However, it did not last long. Likewise, they did not reach nirvana and achieve "consummation" when Jude ended up dying with great regrets. For another thing, the clacker stands for the accusation made by the church and the estrangement from the people around. Both Jude and Sue's pain comes directly from these two things.

"The air increased in transparency with the lapse of minutes, till the topaz points showed themselves to be the vanes ... The foreground of the scene had grown funereally dark, and near objects put on the hues and shapes of chimaeras" (Hardy, 2010, p. 15). This is another episode taken from the novel. It draws us a picture of the famous Christminster and of what it looks like in different conditions. Prior to sunset, Christminster presents Jude a grand new vision of the world: ancient, venerated and resplendent. It doubtlessly reinforced his inclination to go for study in Christminster, the "holy temple". While what happened posterior to sunset is totally on the opposite side. Christminster seemed to be awfully in a picture frame of ghastly chimaeras. Despite what it seemed on the outside, spick-and-span, very beautiful, bright and impressive in appearance under the world's attention, it was spooky, grim and sinister inside. Christminster is actually a place fraught with brutality, hypocrisy and hierarchy. This is a symbol set as a shot at Jude' tragedy later on.

\subsection{Hardy's Pursuit for Optimism Towards Life}

"Tragedy in general is a literary work in which the protagonist meets an unhappy or disastrous end. Unlike comedy, tragedy depicts the actions of a central character that is usually dignified or heroic" (Guo, 2012, p. 18). Each hero has his weakness of nature. There are also sharp conflicts between the individual and the evil force in the society. Jude completely conforms to the above two conditions, but one thing needs considering is that he is not a hero, but an ordinary person. Actually, its types generally cover hero tragedy, family tragedy, tragedy of the little and tragedy of fate. By this token, Jude the Obscure is no doubt a tragedy. Hitherto Hardy is definitely labelled in a pin-up category - a pessimist. In fact, tragedy is just a type of literature, a form of drama and a projection of emotion. Although Hardy once said: "Happiness was but the occasional episode in a general drama of pain", what the novel displays is still the pursuit for optimism towards life. Life is a struggle; man has very little time to enjoy himself. Most of the time, he is fighting for his dream against the reality. Maybe his suffering repeated defeats is a tragedy, but it can leave us a space to reconsider. Through Jude's distressing death, broken marriage and unsuccessful dream of going to university, Hardy wants to attack the abnormal marriage system and social moral; convey the readers the new rising forces and its great influence and coverage; courage people to resist anything old, unreasonable and deceptive; let people see the world as it was which is ugly; show the pursuit for optimism towards life.

\section{Hardy's Representation of Courage to Face the Harsh Reality in Light of Darwinism}

Being the core idea of Darwinism, the Origin of Species is widely applied in Hardy's works, like Jude the Obscure (1895). Deeply affected are even the most famous series "The Novels of Character and Environment" novels set in Wessex. Hence, the followings are intended to explore the issue of how Hardy show his idea through a series of actions of a single person or a group of people in light of Darwinism.

\subsection{The Conflicts Between Characters and the Society}

"Darwinism think that those who survive in the world are the fittest and those who fail to adapt themselves to the environment will perish. They believe that man has evolved from the lower forms of life and humans are special not because God created them but because they have successfully adapted to the changing environment 
conditions and have passed on their survival-making characteristics genetically" (Guo, 2012, p. 212). And it is Darwin's theory of revolution that dealt the fatal blow to religious belief. In the theory of natural selection, and survival of the fittest, it is obvious that the successful survival of the characters rely on their adaptability to the environment. The best proof is the definition of Darwinism that in a narrow way it refers to the theory of evolution put forward by Charles Darwin through his studies on the origin of species and the natural law of biological evolution in The Origin of Species; while in a broad way Darwinism also incorporates ideas of the works by some other thinkers of evolutionary theory like Herbert Spencer and Thomas Henry Huxley. Hardy once wrote it in a letter that: "My thought is in alignment with that of Darwin, Huxley, Spencer, Comte, Hume and Mill. I read the books more of them than Schopenhauer." In the novel Jude the Obscure, Darwin's theory of revolution is indeed widely applied in the description of the conflict between character and environment. And the theory of natural selection and survival of the fittest has a profound effect on the characters. The evolutionary storm that Darwin blew up in the Victoria age in Britain swept like a fresh wind through the natural science and literature, bringing in its wake a new climate of intellectual and academic freedom that has grown with the passing years.

\subsection{The Survival of Mr. Phillotson and Sue Adapting to Their Environment}

At the end of 19th century, capitalism was at the period of great prosperity. The industrial capitalism has seen great changes taking place in Britain: mass production of machinery, global expansion, the rapid process of urbanization and industrialization and unprecedented opportunities. But along with it are many serious social problems, such as the widening gaps between rich and poor, frequent economic crises, massive unemployment, rural poverty and the bankruptcy of private farms, contributing to more social conflicts. So, the Victorian age was a time of crisis and confusion. In this respect, a short excerpt was taken from the novel. "Though Farmer Troutham had just hurt him, he was a boy who could not himself bear to heart anything ... He carefully picked his way on tiptoe among the earthworms, without killing a single one" (Hardy, 2010, p. 11). Hardy here clearly states that Jude, weak and irresolute, was bound to suffer great pain and with this logic death was the most liberating experience he can have. Character affects Jude in every aspects of his life and finally contributes to his death. The reason lies in Jude's being unable to adjust he himself to adapting and integrating into the society. Undoubtedly, Mr. Phillotson is really the best example of the theory of natural selection and survival of the fittest. He realized what sort of society he lived in, so he kept with the trend of his time and lived his own life, which is just fine. Hard life as Sue lived, comparatively speaking, her fate is at least better than Jude's. Now that Sue made up her mind to face a new life, she must be able to withstand anything that will happen. For her, a woman with modern mind, it was just a comparatively simple challenge. Wallowing in despair and sorrow, Jude ended up dying of consumption at only thirty.

\section{Hardy's Exploration of Rationality in Religion and Feminism}

Not to mention the memories the author has in his childhood, all types of fate the main characters have in his lifetime, the age alone in which Hardy lived is full of crisis, confusion and many serious social problems. Hardy straddles two centuries, having been brought up in Victorian age and later going through the changes and facing to the future 20th century. With Darwinian making people realize that man is the master of nature, the cohesion of Christian Church continues weakening or even disappearing. Religious differences have given birth to many sects. Oxford movement, especially the Catholicism got its footing in academia. So, the whole British society was undergoing belief crisis. Then Britain was in a period of transition from the end of Victorian age to the beginning of the modern age. The so-called "first wave" of Women's Liberation Movement happened in the late 19th century which aims to eliminate forms of oppression based on gender and to gain for women equal economic and social status and rights. Under such circumstances, Hardy, like many other contemporary writers, embodies the religious rebellion and feminism in his works.

\subsection{The Counterplea of Religious Curse in Sue and Jude's Marriages}

Affected by Barnes, the linguist and poet, Hardy started reading the Bible in his teens. Accordingly, most people pointed out that the core of the Bible, the original sin, had a far-reaching effect on Hardy's tragedy consciousness. It is speculated that Hardy held the view that human right after the birth was doomed to atone for his crime and suffer from pains. However, it is actually not. Many plots set in the novel are the reflection of Hardy's willpower as well as his religious rebellion. And Jude and Sue are endowed with the thoughts and voice of Hardy. "My niece and her husband, after they were married, didn't get a house of their own for some year or more; ..." (Hardy, 2010, p. 8). "“Another, that it was always impressed upon me that I ought not to marry- that I belonged to an odd and peculiar family - the wrong breed for marriage.' 'Oh, but there can't be anything in it!', 'Our family have been unlucky of late years in choosing mates - that's all.'” (Hardy, 2010, p. 157) However, after 
reading the whole story, it is clear that it is actually not an affirmation of original sin, but a tendency to religious rebellion. The reasons are as follows. To begin with, Jude and Sue lay eyes on each other and got "married". They gave no heed to the curse, the wrong breed for marriage and the marriage certificate proved by the church. In the next place, Jude was of innocent youth beginning to understand love when he met a most sophisticated and sexiest woman Arabella. Arabella tried all means to seduce Jude. Her beautiful hair and attractive dimples were all tricks she carefully planned. Consequently, Jude was bewilderedly deceived into marrying her as his "intended partner". It was too late that Sue knew Jude had married, for she has already fallen in love with Jude. Thus, she was angry, mad and sad, and married an elementary school teacher. In like manner, Sue's marrying Mr. Phillotson is not out of love but because of retaliation. What Sue said is scientifically justifiable. Their family has been unlucky of late years in choosing mates, not the old curse. Last but not least, if the original sin holds true for everyone, then how to explain Arabella's "colorful life"? No matter how cruel it is, she managed to get anything she wanted, including Jude, Jude's belongings and other rich men. She was a skittish and material woman, abandoning Jude and Little Father Time and was itching to Jude's possession. Arabella was guilty of great wrong against God and humanity. Logically speaking, she deserved the punishment, whereas she lived a better life, at least better than Jude and Sue. As for this, the original sin can't make a reasonable explanation.

\subsection{Hardy's Expression of Glorification of the Rebellious Sue}

In British history, the Victorian age can be somewhat comparable to the period of Chinese feudalism in terms of women's social status. Women could not live their lives in their own will. The development of their personality as women was fettered by the view that men are superior to women. Politically, women have no equal right of political participation. Economically, men were endowed with the disposal right of all properties and the management of the whole family; whereas women were absolutely the "proletarian". In educational term, there was strict limit to women's getting the right to receive education. By marriage, women were regarded as the subordinate to men, having no independent personality at all. From the perspective of physical condition, it was high fashion that women should be laced in. Throughout the whole process of corset, women had to bear great anguish. However, the economic and social development in this period provided women with an access to changing their lower social status. Seeing all this, Hardy naturally showed his glorification of the rebellious women.

By means of the praise of women, Hardy also delivered a sense of rationality in a round-about sort of way. Hardy has been made the mark of a voluntarist affected by the German philosopher Shopenhaver (Ding, 2008, pp. 61-66). In this case however, a sense of rationality can be seen throughout the novel easily and clearly. Above all, if Hardy was a voluntaris, he can just alter the fate of any role arbitrarily and then make up a new ending. If Hardy was a voluntarist and he wanted to write tragic novels, Sue and Mr. Phillotson could all be dead, leaving Arabella lived a happy life. If Hardy was a voluntarist and he did not want to write tragic novels, Jude and Sue could escape from Britain and live together in other places; Mr. Phillotson married a fair lady ... However, neither of them is the ending of the novel, which turns out that Hardy is not a voluntaris. He knew that where there was oppression, there was resistance; where there was resistance, there was sacrifice. So, Jude the obscure is set as the victim of the conflict. He praised Sue as a woman in new era, but he knew at the same time that feminism was just emerging and was doomed not to go on smoothly and successfully. So, Sue compromised to desperate plight. What's more, like Mr. Phillotson, Sue realized what sort of society she lived in, so she kept with the trend of her time. Sue learned how to dissociate emotion from reason, for she knew marrying Jude did no one any good; reason surpassed emotion. Thus, Hardy saw the situation and understood what it is. He is a rational novelist, creating his works under the historical background and social environment.

\section{Conclusion}

Jude the Obscure is one of Hardy's masterpieces. At the time of the novel's composition, Thomas Hardy (1840-1928) was living between the turn of the 20th century and the eve of the 19th century. The Victorian age is an eventful period, during which great changes have taken place. Schopenhauer's mysterious theory of voluntarism and gloomy pessimism, as well as the rudiment of feminism made a notable impact in Hardy's theme creation. It is widely accepted today that Hardy is a pessimist and voluntarist. Some people even argue that the female image in Jude the Obscure was appreciated by the author, but it also made the author sigh with regret. And Sue's consciousness of feminism started to awaken, but lack of thoroughness (Gong, 2011, p. 15). However, after analyzing key steps, a three-phase pattern, in the theme creation, it is found to differ from the previous view completely. By way of the analysis of the use of symbols and images, Darwin' Theory of Evolution, the conflict between character and environment, the expression of religious rebellion and the advanced female image, it can be concluded that Thomas Hardy is not a pessimist and voluntarist at all and the novel conveys readers the kindness tendency, the courage to face the harsh reality and a sense of rationality. 


\section{References}

Ding, S. Z. (2008). The Eco-ethic Consciousness in Jude the Obscure. Journal of Changjiang Normal University, 4, 61-66.

Foster, E. M. (2009). Aspects of the Novel (p. 82). Beijing: People's Literature Publishing House.

Frye, N. (1957). Anatomy of Criticism. New Jersey: Princeton UP.

Gong, C. T. (2011). The female images in Thomas Hardy's "The Novels of Character and Environment". Thesis, Shanghai Normal University.

Guo, Q. Q. (2012). Combing and Refining the Points for Postgraduate Examination for English Majors (British and American Literature). Jilin Publishing Group Co., Ltd.

Richard, T. (1981). Understanding the Elements of Literature (p. 32). London: St. Martin's Press, Inc. https://doi.org/10.1007/978-1-349-16773-9

Thomas, H. (2010). Jude the Obscure. Xi'an: World Book Inc. https://doi.org/10.1017/CBO9781139541206

\section{Copyrights}

Copyright for this article is retained by the author, with first publication rights granted to the journal.

This is an open-access article distributed under the terms and conditions of the Creative Commons Attribution license (http://creativecommons.org/licenses/by/4.0/). 